project in applied silviculture on the UNB woodlot. Professor Thompson will lecture in forest management and conduct forest protection laboratories.

\title{
CORRESPONDENCE ${ }^{1}$
}

Secretary, Canadian Society of Forest Engineers, 10 Manor Road West, Toronto 12, Ontario, Canada

Dear Sir:

I am trying to locate a forester by the name of Knute Eckholm of Ontario and wondered if you could supply me with his address.

If not, could we locate him through the medium of the Forestry Chronicle.

74 John Street, Kingston, New York.

Very truly yours, Stanley Mesavage, Manager, Mid-Hudson Forest Products Co-operative, Inc.

1. Editor's note -if any reader has information regarding Mr. Eckholm will he kindly advise. FORESTRY IN SCOTLAND

A course on Forestry in Scotland will be held from the 11th to the 23rd September, 1950 inclusive, under the auspices of the British Council and arranged by the Forestry Department of the University of Aberdeen, in conjunction with the Forestry Commission. Four days will be spent in the University of Aberdeen and nine days on a tour through North and Central Scotland.

This course is intended for staffs of State Forest Services and of Academic and Research Institutions in Commonwealth and foreign countries. The course will be limited to twenty members who must be proficient in English.

The estimated cost from London back to London including board and residence for the duration of the course and transport charges will be $£ 28$ per person. Accommodation will be reserved in hotels.

Further information, including method of application, can be obtained from the Area Officer, British Council, 22 Bridge Street, Aberdeen.

FORESTRY IN SCOTLAND

Scotland offers much of interest to forestry experts. It is the western limit of the natural distribution of Scots pine (Pinus silvestris) in Europe. The native pine is a distinctive maritime strain or rather consists of different strains. The so-called Scottish race of European Larch (Larix decielua) has for long interested silviculturalists in many countries. Research has been proceeding in the University of Aberdeen on the morphological variations of the Scots Pine and European Larch in Scotland. The Hybrid Larch originated in Scotland; this species has also been the subject of research in Aberdeen. Scotsmen, such as Archibald Menzies and David Douglas, were pioneers in the introduction to Europe of North American trees. In the middle of the last century the Oregon Association, a society of private woodland owners, was responsible for several important introductions. The famous private collections of Conifers in Scotland and the intensive use of several of 
them in afforestation are of wide interest both to North American and European foresters.

Both before and since the formation of the Forestry Commission in 1919, important research and experimental work has been carried out in Scotland on the afforestation of Peat moorlands, Upland Heaths and Maritime Sand Dunes. Again with a large State programme of afforestation, research and practice in the raising of forest plants are highly developed.

The British Government scheme for the dedication of British woodlands, designed to revive and extend private forestry in Britain, has attracted wide attention.

The course will cover lectures in all these topics and many of the most interesting forests, both from the research and the practical points of view, will be visited.

\section{PROGRAMME}

11th Sept., 1950:

Assemble in Aberdeen. General sightseeing and talk in the evening on history of Scotland, Aberdeen and the University.

12th, 13th, 14th Sept.:

Lectures in forenoon sessions in the Forestry Department, University of Aberdeen. The subjects will include: History of Forestry in Scotland; The Use and Growth of Conifers, Native and Exotic in Scotland; Races and Strains of Conifers in Scotland; Organisation and Work of the Forestry Commission; Private Forestry; Recent Research in Forest Nursery Practice; Choice of Species; Treatment of Maritime Dunes, Upland Heaths and Peat Moorland.

The lecturers will be partly members of the University staff and partly invited Forestry Commission and other experts.

There will be one afternoon excursion to Lower Deeside to see a collection of exotic conifers.

The other afternoons will be free for demonstrations and special talks and for other than forestry interests.

15th Sept.:

Leave Aberdeen for Lossiemouth, visiting Teindland Forest enroutewasteland nurseries and afforestation of difficult heaths.

16th Sept.:

Newton Nursery, Monaughty Forest and Darnaway Forest-nursery research and practice, exotic conifer plantations and private forestry.

17th Sept.:

Leave Lossiemouth for Culbin Forest-afforestation of maritime sand dunes. Proceed to Inverness in the evening.

18th Sept.:

Visit Black Isle--upland heath and moorland afforestation; deep ploughing and planting, podsols with pan, etc.

19th Sept.:

Visit Inchnacardoch Forest, Fort Augustus-Ion Mhor Peat Experimental Area-afforestation of peat and provenance plots of Scots pine. 
20th Sept.:

Leave Inverness for Kenmore or Aberfeldy. Visit en route selected Scots pine stands and natural regeneration in the Spey Valley. 21st Sept.:

Visit Drummond Hill Forest, Perthshire-use of European, Japanese and Hybrid larches and provenance plots of larches.

\section{2nd Sept.:}

Proceed Kenmore to Aberdeen via Devil's Elbow and visiting en route the Parent Larches and Hybrid Larch woods at Dunkeld, Perthshire, and natural pine forest in Upper Deeside.

23rd Sept.:

Aberdeen-Forenoon, general discussion on what has been seen to complete the meeting-Disperse.

\section{UNIVERSITY OF NEW BRUNSWICK SCHOLARSHIPS}

The names of 10 forestry students of the University of New Brunswick who have been awarded C. H. L. Jones scholarships of the value of $\$ 5,000$ were made known on November 18 in Fredericton by Dr. A. W. Trueman, president of the university.

The scholarships, which were established by the Mersey Paper Co., are named after the late Col. C. H. L. Jones who was president of that corporation when the decision was made in 1947 to found this scholarship plan.

The scholarships are offered in open competition in the U.N.B. department of forestry. It is provided that one scholarship be awarded to a graduate student working towards a master of science degree. The remainder are divided equally between final, fourth and third year students. The scholarships have a total value of $\$ 5,000$. Each scholarship is worth $\$ 500$.

The successful applicants are: Raymond J. Finnegan, 537 St. Sacrament Blvd., Shawinigan Falls, Que., winner of the graduate scholarship; George T. Silver, Hemford, Lunenburg Co., N.S., George A. Hamilton, Parry Sound, Ont., Reginald J. McCormach, 298 King St., Peterborough, Ont., senior scholarship winners; Leon R. Pond, 1332 Jean Nicolet St., Three Rivers, Que., Robert G. McCullough, 54 Havelock St., Brockville, Ont., Victor H. Bushell, 207 Randolph Rd., Leaside, Ont., fourth year winners; and John S. MacTavish, 74 Chesterfield Ave., Westmount, Que., Charles E. Potter, 1575 Summerhill Ave., Montreal, Que., Cecil J. Smith, Swan River, Man., winners of the third-year scholarships.

Dr. J. Miles Gibson, dean of forestry at the university and chairman of the selection committee, stated that keen competition made the selections difficult. He said that the 10 students finally chosen for the awards had all done work of a high order since they had been at the university, and had clearly demonstrated their ability and qualities of leadership.

According to Dean Gibson the scholarship awards were based chiefly on the 1948-49 academic records of the applicants, but character and financial need were also taken into consideration. 